\title{
Ethnologies
}

\section{Odours and Boundaries} Bora-Miraña Construction of Territoriality (Amazonia)

\section{Dimitri Karadimas}

Volume 35, numéro 2, 2013

URI : https://id.erudit.org/iderudit/1026554ar

DOI : https://doi.org/10.7202/1026554ar

Aller au sommaire du numéro

\section{Éditeur(s)}

Association Canadienne d'Ethnologie et de Folklore

ISSN

1481-5974 (imprimé)

1708-0401 (numérique)

Découvrir la revue

Citer cet article

Karadimas, D. (2013). Odours and Boundaries: Bora-Miraña Construction of Territoriality (Amazonia). Ethnologies, 35(2), 183-201.

https://doi.org/10.7202/1026554ar
Résumé de l'article

Le concept de territorialité est souvent lié à une appréhension plus globale du sol considéré comme étant limité par les frontières avec les groupes voisins. Chez les Amérindiens Bora-Miraña de l'Amazonie colombienne, il semble que cette notion de territorialité n'est pas tant liée à la délimitation factuelle et spatiale des frontières de fait qu'à une notion plus vague d'odeur ou de senteur territoriale. Cette notion repose sur la perception de la santé des individus et des maladies considérées comme étant répandues par d'autres groupes ou par des animaux perçus comme ennemis. La virulence des " Autres " ne peut alors être contenue que par une odeur locale plus forte qui caractérise le soi.
Ce document est protégé par la loi sur le droit d'auteur. L'utilisation des services d'Érudit (y compris la reproduction) est assujettie à sa politique d'utilisation que vous pouvez consulter en ligne.

https://apropos.erudit.org/fr/usagers/politique-dutilisation/ 


\section{ODOURS AND BOUNDARIES \\ Bora-Miraña Construction of Territoriality (Amazonia)}

\section{Dimitri Karadimas}

Laboratoire d'anthropologie sociale, CNRS

It is only when we come to represent local differences in terms of a globalising discourse that the centre from which each perspective is taken is converted into a boundary within which every local view is seen to be contained. The idea that the "little community" remains confined within its limited horizons from which "we" - globally conscious Westerners - have escaped results from a privileging of the global ontology of detachment over the local ontology of engagement. (Ingold 200: 216)

The main topic of this article is a presentation of concepts of border and territory as found in an Amazonian Amerindian society. This presentation is possible thanks to an ethno-historical survey that permitted a brief sketch of the social and cosmological variations created by forced deportation of a Northwest Amazonian indigenous society into three different countries.

\section{Boundaries and memories}

I will begin this article with the evocation of some fieldwork anecdotes. When I was visiting the Miraña of the Colombian Amazonia for a stay of long duration in 1992, the local leader, following a cycle of shamanic cures, had decided to carry out a great ritual (the Snowy Egret Egretta thula ritual). During this ritual closely tied groups (mainly of other Miraña clans and the Yukuna groups of the Caquetá River) were to take part. This time, however, benefiting from the presence of the son of a Bora living on the upper waters of the Cahuinari River and moving through the Igara-parana, the invitations arrived with their intermediary to the Bora of Peru. Nobody really thought that the Bora would come. A few days before the beginning of the ritual, one month after the invitations were issued, the community in which I lived saw some Bora from the Peruvian territory disembarking from a big river canoe to accompany the Miraña in their ritual. 
These Peruvian Boras took a stroll around the community village of Puerto Remanso del Tigre. They stopped opposite the house of a North American missionary of the New Tribes Mission and, amazed at the palisades which surrounded it, could not keep from making the following comment: "It is sure, here lives a White!"

The Bora were perfectly aware of the successive limitations with which they had just been confronted: borders of the national states on one side, and the division between two worlds, theirs and that of the Whites, on the other. Finally, within this latter, White "nationals" - Colombians or Peruvians, with whom they were asked to identify themselves - and others, foreigners, North American or European.

However, as much as they seemed to be superbly unaware of the requirements of the first of these limits (no request for a passport or visa, and no declaration of entry to the authorities of these two national states: the idea even appeared absurd when I formulated it to them), they were more sarcastic about the second of these limitations. Here they were in the enclosure of a village under Miraña authority and the pretension of the missionaries' materialisation of these borders by a fence made them derisive with respect to their Miraña fellows.

These anecdotes are telling: the concept of territory - as supposedly linked to that of boundary - causes serious problems in the Miraña customary system of thinking. I will give as an example the case of a colonist installed in the same Miraña village of the preceding anecdote. The house that the colonist made was located in an old orchard. According to the Miraña custom, the fruit trees are the property of the one who plants them; one can change place of residence, but the memory of an orchard giving fruit always attracts its former owner or his descendants when they still know of its existence. One thus often sees people returning to an old dwelling place to gather fruit that took more time to grow than did the actual residence in a given location (between 7 and 10 years). These old dwelling places are usually not taken as new places of residence until the primary forest can remove the old traces of anthropogenic uses. In this case, there are thus no possible conflicts between newcomers and former growers of fruit trees and, even if there were, the right of the "planter" takes precedence over that of the inhabitant. The situation is quite different with the colonists.

When the indigenous authority allots a plot of land to them, they react as colonists and consider that the whole of the piece and what it contains is their property, hastening, generally, to materially delimit this acquired space 
with a fence, a palisade or netting. The former inhabitants thus take a dim view of the fact that the newcomers briskly help themselves to fruit that, in their eyes, is still their property. From one year to the next, wanting to pre-empt the colonist's abusive gathering, they hasten to go to collect the fruit first. This gathering is opposed by the colonist on the pretext that the former inhabitant is at his place, on his ground, and that people come to steal his fruit. The conflicts of vicinity become impossible to circumvent and the arbitration of the indigenous authority always leaves a taste of injustice in the mouth of the colonists who, in fact, feel ridiculed in their rights.

But to the Miraña, specifically, the Other is not necessarily the neighbour: territory is not a creator of borders, and the gradation from the close to the distant does not imply territorial distinction. In other words, territoriality is only partially the founder of an ontological distinction. My intention is thus to give an account of this gradation between the close and the distant, in the way in which the interested parties conceive of their relation to the territory, and according to what criteria they estimate "being at home." This work is ethnographic and gives an account of an internal point of view of the Miraña society.

\section{The "Bora" and "Miraña" ethnonyms: an outside construction}

Let's start by defining of whom we are speaking. The two terms "Bora" and "Miraña", by which these ethnic groups are today named, appeared only late in the ethnohistoric sources. Before T. Whiffen (Whiffen, 1915) and since the first ethnohistoric sources which go up to the seventeenth century, there existed only "Mirañas." This term is built in lingua geral - a Tupian based lingua franca - in a similar mode to that of "piranha," which means "toothed-fish," but with mira, "people", in place of pira "fish".

Miranha, or Miraña - according to the Spanish written form - are "Toothed-People", "Cannibals", a name which included other populations who are known today by these terms: Andoque, Uitoto, and even other populations of the middle reaches of the Caquetá were named as such by the inhabitants of the lower Caquetá-Japurá during the historical period (Karadimas 1997).

The "Bora" and the "Miraña" never recognized themselves as such, just as a North American never refers to himself as a gringo - except with a certain irony when adopting a foreign reference "Soy gringo..." - even if he is perfectly able to recognize that this appellation, in the mouth of another, is supposed to be addressed to him. However, the use of these terms for more 
than two centuries in the Colombian Amazon, either by the representative of national authority or by the other indigenous communities, has now been incorporated into Spanish as a communication language. The group has also now taken the terms to name themselves as a separate entity from other groups of the area.

The name that the Bora and Miraña people apply to themselves, "The Real Persons" (míamúinaa), differentiates them from all of the other populations - indigenous and non-indigenous- according to two principles: the first distinction is made between "human" and "non-human", and does not inevitably intersect our human/animal distinction. The second one is a distinction that takes place among indigenous populations, according to an opposition reflecting the way they estimate the beliefs of the neighbouring groups (see below).

Indeed, according to the first distinction, other "beings", like spirits or entities, can be qualified as "human"; whereas, other humans are perhaps lesser forms of "beings," referring by this to certain qualities supposedly present in "humans" and absent in "non-humans" (qualities that are shamanically recognised, see Karadimas 1997). The distinction, which could be an example of an ontological boundary, appears here already to act more as a gradation than as an opposition, eliminating the idea of boundary as possession of innate ontological qualities. One is more or less human according to the presence or absence of those qualities.

In the second distinction close groups are partitioned according to two categories: "People of God" (Nìmúe Múinaa) and "People of the Animals" (İame Múinaa). This distinction is based on the way different groups are supposed to do their shamanic cures. In the Miraña's eyes, "People of God" refer to the Creator as the major spiritual helper. To the contrary, the "People of the Animals" do their cures by referring to animal spirits. The category of "People of God" includes the Miraña and most of the ethnic groups of the Caquetá/Putumayo region (Miraña, Bora, Muinane, Uitoto, Ocaina, Nonuya, the now gone Resigaro, and the Aróhtt'e known in the region since the 1970s as "Caravallos" - according to the name of a Colombian boxer in vogue at that time - and who probably are the former Uainuma named by Martius at the beginning of the nineteenth century) (Spix and Martius, 1980 [1831]). Although from different linguistic families, these ethnic groups share a common cultural background, invite each other to the same rituals, and have ritual partners and enemies among them. The category of the "People of the Animals" includes mostly groups living north of the Caquetá like the Yukuna, Matapi, Letuama and Tanimuka from the 
Miriti-paraná and Apaporis rivers to which the whole Tukanoan speaking groups of the Vaupès region must be added. The Carijona, a Carib speaking group from the upper Appaporis River, who were the former enemies of the Miraña until a demographic decline in the mid-nineteenth century for unknown reasons (see below for the ethnohistoric account), can be added to this latter category.

All of the groups belonging to the first category (People of God) share a common territory that covers, roughly sketched, from the southern bank of the Caquetá to the Putumayo River (Colombia's present frontier with Peru). The populations in this region are designated by the Miraña as "People of the Centre" or "People of the Middle" (Ptnè Mrtinaa), in the sense that this is the centre of the world. People from the other category live on the northern riverbank of the Caqueta and on the other side of the Putumayo and are represented by the Tikuna, Cocama and Yagua people of the southern border of the territory. It is thus possible to affirm that the Miraña know where and who they are: they are the "Real People" living, with others, as "People of the Centre" (of the world), surrounded on each side by People of the Animals. In a sense, it is a perfectly ethnocentric way of defining the social Self, with the major restriction that it is a macro-cultural way of defining this Self since it is not limited to an ethnic/linguistic unity.

In ancient times - until the rubber period - there were also names given to certain territorially marked groups or sets. According to my informant, the groups known today as "Miraña" were divided into three main geographical units from the Córdoba rapids upstream of La Pedrera on the Caquetá to the Pama. These were the "True Miraña," he says, meaning by that people who were not speaking dialectical forms of Bora. The Kò:mîtimì hè "People of the milpeso palm tree" (Jessenia bataua) were located from the Córdoba rapids (the ancient Cupatí Falls) to Puerto Miraña on the Caquetá. The Gwàimút hè or "Mosquito People" lived between the former Pt. Miraña on the Caquetá and the mouth of the Pama on the Cahuinari River. And, finally, the "Gluttonous meat-devouring people" (dòópiry àmì hè ${ }^{l}$ ) populated

1. Litt. "Gluttonous meat-devouring people”: dóòpí: “to eat meat with excess, devour", $r^{y} \grave{a}$ : aff. frustrate, mú: suff. plur., hè: "patrilineal filiation group", but used here, in extension, for a whole, or a set of clans, that can fit various of them. I want to thank linguist Frank Seifart for helping me with the precise translation of this term (which I -only in part- erroneously translated as "Dark meat-devouring people" in my $\mathrm{PhD}$; see Karadimas 1997: 77). J.-A. Echeverri (2002: 169, notes 9 and 10) has recently focused on the fact that present-day Miraña leave this later qualification out of the name of the indigenous organisation that they founded, to not exclude other non-Miraña people of the area (for now, one PANI). Echeverri 
the Pama. Actual Miraña clans living on the Caquetá came from this later set. The recent creation of a Miraña indigenous organisation called PANID Pinè Áỉ éhit Nimute İátšimútà Dòópiryàmit hè for "Meat-devouring People, Grandsons of God of the Leader of the Centre" refers to this set of clans. The main occupation area was thus, according to the traditional memory of the Miraña, part of the Caquetá, part of the Cahuinari, and the Pama.

At a more global level, the Miraña territory is thus in a relationship of opposition of centre/periphery with other cultural sets; although the "edges of the world" are occupied, with "people of the animals", the main communication axis is the west-east flow of the Caquetá River. The east is the old territory of the Tupi groups of the Amazon centre. This has been replaced in Miraña cosmogony by the Whites ("People that fire, or that burn"), whereas the west is regarded as an elevated territory, called "territory of the stars" through which one reached, in the past, the territory of the groups of the upper Caquetá and the Colombian Andes.

However, there is no indigenous category that gathers the totality of the Bora and Miraña (with the Muinane, they are from the same linguistic family with no other known member on the rest of the continent). The Bora and Miraña live in sets of communal houses remaining temporarily under the pacifying responsibility of a "Powerful" (the Kéề which is a supra local authority - much more a counsellor - with no territorial unity, that can be compared to a cacique). The local filiation groups (clans) were organised in houses; but each house did not only shelter people of the dominating lineage. Still, a supra local hierarchical level did exist as well. It could have sometimes included a score of communal longhouses (malocas); but they remained independent one from the others and recognised political bonds only with the conciliator. These regroupings were temporary and related to the person in the position of the conciliator: they did not form a major political unit built on territorial unity (and were not the same as those sets of clans to which I will further refer). The traditional territory of the Miraña did not include an overall supra-clan and, even when there was a grouping between several local communities, it was done according to an adhesion of several local chiefs to a supra local advisory authority. These sets related to local people, malocas or communities, but not to territories. Thus, a cacique or "Powerful" could have several malocas under his responsibility but, they were dispersed, and formed only rarely a territorial continuity.

also kept as a translation of the former dòópiry àmì hè the formulation "Grandfather of the Miraña" which, it has to be noted, is not a translation, but a designation of what the term refers to. Dòópiryàmì hè refers to a set of clans that were designated as "Meat-devouring people". 
In this sense, a major socio-political unit that could have covered the Miraña people did not exist. The whole of the Caquetá-Putumayo region does not seem to have been organised according to strict ethnic/territory delineation. Although every ethnic group could locate any other, they were not bound to a particular territory.

\section{Ethnohistoric glance}

Coming from different historical situations, the Bora-Miraña's present location is the remote territories of three Amazonian states: Colombia, Peru, and Brazil. Although the distribution of their "traditional" (historical) area at the beginning of the seventeenth century was the Japurá/Caquetá River, their present location is definitively the result of antagonisms that accompanied the definition of those states' boundaries. The Miraña community of Tefé (Brazil), who no longer speak their own language (see Faulhaber, this publication), arose from the first contacts between inhabitants of the Upper Japurá/Caquetá and Portuguese traders during the eighteenth century. This first commercial contact quickly transformed into exploitation through slavery where the Miraña became as much victims as traders of human merchandise (Karadimas 2000). For more than a century, slaves from the Upper Japurá/Caquetá flooded the central Amazon region constituting part of the present population; Miraña's Tefé community is formed from those deported descendants.

The present situation of the Peruvian Bora and Colombian Bora-Miraña is the result of an historical upheaval linked to the rubber tree extraction period at the beginning of the twentieth century, and to the ColombianPeruvian boundary conflict of the 1930s (Dominguez and Gomez 1994). At the same time that the Peruvians lost part of the territory to Colombians, owners of rubber tree extraction companies deported the indigenous workers to the Peruvian territory. There, trying to recreate indigenous life after the breakdown of the entire rubber industry, they formed the presentday Peruvian Amazon's Bora and Witoto communities who only recently tried to make contact with their Colombian relatives. The Miraña, on the opposite side, stayed during the same period in Colombia, and fled to the north, into Tanimuka, Yukuna and Makuna territory to escape the rubber extraction companies. They returned only after the Second World War when the rubber extraction period definitely came to an end.

Nowadays, local situations appear completely distinct from one country to another. It seems that the present situation does not involve mutual 
aid between those historically linked groups. It can be said, however, that current contacts between communities that split up in the historical period show a clear desire to rebound with a group identity that imploded under the pressure of human and rubber extraction. Those local but trans-boundary initiatives tried - by taking their alter-ego from the other side of the frontier as an element of comparison - to strengthen their local influence. The webs that those aggregated communities developed - and which are built up around important traditional rituals - today reveal that a new form of contrasted identity is developed near regional and trans-boundary cohesion.

\section{Memory and lapse of memory: when deaths are too close}

The current filiation groups designated under the name "Miraña" estimate that their localization of origin - what they name their "ground" iñúth - is located on the Pama River, flowing from the Cahuinari. However, this territory is today entirely deserted as the massacres carried out at the time of the rubber period are still so much present in the memory of the Miraña (for a survey of massacres committed during the rubber extraction period see Stanfield 1998: 106-07). In fact, these territories can only episodically be visited, since the presence of the dead is, according to the Miraña, still felt too much. For the Miraña at the very least, deaths do not define their territory. The contrary, however, occurs on the lands of a nation-state. For nation-states, deaths define the lands of a nation, insofar as they mingle with the territory in the imagination of the populations occupying them. However, the toponymy of the landscape and its name are the reflection of these past actions. It is in this sense that the ground is thought of as "pertaining" to a given social unit since it is partly constituted by its own dead, recently deceased or not, and because the living claim to be "organically" descended from the former. So the idea of having "roots" deep inside the land is not just a metaphorical way of representing links with a specific portion of territory; it is also a way of presenting the ground as build up with the corpses of one's own dead: toponymy is the witness. In this sense, it is interesting to note that the anonymous will of extermination always underlies a territorial purification that is accompanied by a change of local toponymy.

This whole practice partly shocks the current indigenous communities since they precisely choose to register their deceased in a space dedicated to the lapse of memory in order not to maintain their dead in this world. Contrary to the construction of memory of a nation-state, indigenous toponymy results primarily from mythology. This temporality tries to 
exclude the historical incidence from its constitution as a group (in such a way that, the Whites and the tradesmen occupy a precise place within the physical and mythical Miraña territory: "Trade-God" is located at Raising, downstream). Still, the deceased are no less present in the memory of the living since people carefully avoid rebuilding where others have buried their dead.

This presence of the dead is also what founds - but in a negative way, i.e. while avoiding naming them- the Miraña sphere of extension. Many "stories" - myths - cannot be told locally without remuneration of the evoked spirit, for he is on the lookout and presents himself to the narrator either in dream or memory and claims his part of coca powder, food and drink. If the name of a recently deceased person is evoked, his ghost can claim a person of the narrator's family in order to feel less lonely; the death of a person who comes from the same family of a recently deceased person is interpreted in this manner by the Miraña (Karadimas 1999).

On the other hand, Miraña informants have often taken the initiative to tell me certain myths or life histories of deceased persons if they were far from their territory, far from where the spirits could hear them and where the ghost cannot present himself/herself to the narrator. Deaths - or at the very least their ghosts, which is not precisely the same as the corpse are thus present and related to a given territory, i.e. the place of the death is also the birth and life place of the ghost. But their presence is doomed to remain absent from personal and social memory. As long as this place is kept in memory and associated by the succeeding generations with a particular person who departed thence, one will avoid referring too much to this place, and, more particularly to residing on it. The remuneration in coca powder and tobacco to the ghost could never calm his hunger. In this way, we see the absence of what could form the basis of a fatherland in the Amerindian manner (see also Taylor 1993: 675 for the Jivaroan case and lack of historicity and deaths).

\section{Mythologized territory vs historical territory}

There is no fatherland in the sense that personal identity is not related to the identification of the person with an institution that includes the territory as a marker of identity. On the other hand, the territory carries the marks of mythological permanence. One example is the Araracuara rapids, a place named according to the mythology, like the Caquetá, "Tapir River" or the Cahuinari, which is the primordial tree that linked the earth 
with the sky and had to be felled to create time, etc. By this fact, the Miraña territory is a space in which the knowledge and the tradition of an impersonal memory fit more than factual and historical action.

This point of view must, however, be moderate; insofar as the east, for example, became, as we have already seen, since the historical period of contact with the world of the Whites, a place from which goods and diseases come, and towards which the slaves set out again. In the face of the intrusion of a new population in the area, the Miraña people gave them a particular place by referring to them as a "Trade-God", i.e. by passing them into the permanence of the myth, historically linking it to the river mouth, raising and revival. In this sense, and according to a mythologized reading of the territory, it became altogether normal that Whites, previously anthropophagous because thirsty for slaves - for the Miraña, the real end of the war prisoner was during the cannibal ritual - came from the East, the raising territory, i.e. the territory of the sun; an anthropophagous entity that nourishes itself on the vitality of humans.

This mythological reading of the territory also allows the Miraña which I also think applies to the other groups of the area - to be in a double relation with the surrounding toponymy: the timelessness and the permanence of an impersonal link to the territory detach them from the interpersonal questionings which the temporality of the colonists, as well as a "hispanization" of local toponyms, introduces (current Mariapolis on the Caquetá, for example, was in the recent past called in Spanish Maria Manteca "Fat (grease) Maria", itself a Spanish phonetic approximation of the miraña Márìmtttúthè: "Shaft of the birds' down").

\section{Tying knots to bound Territory}

If we continue this mythologized reading of the territory, it appears that certain places are more important than others because a particular mythological action has been held there. Those that generally grab the attention are the topographic accidents: the falls, rapids, rock exposure, permanently flooded zones, lakes, swirls, particular tree concentrations, sources and mouths are systematically indexed and memorized. My principal informant, for example, though blind, knows more than one hundred named places only for the neighbourhoods of the locality of Pt. Remanso del Tigre. There are ten times more for the Caquetá or "Tapir River" and as many for all of the Cahuinari, the Pama, etc. The mode of memorizing is double: it makes conjoined lists of toponyms that follow an upstream/ 
downstream succession and/or conversely for the rivers or in a successive link for toponyms that are within a terrestrial path.

In the second place, the "histories," i.e. myths, generally proceed through time within the territory. Certain myths thus directly refer to the creation of the major topographic accidents, or, quite simply, of the general configuration of the territory (falls of the cosmic tree, its bark, the resting place of the primordial Anaconda, the palm tree of the Macaw hole, residence of the female dolphin etc; respectively the Cahuinari, the Pama, a lake of the Cahuinari before its mouth on the Caquetá, the Araracuara rapids, those of La Pedrera, referring here only to the most important toponyms). To travel becomes a displacement, not only in space, but also through a course in the myths and, thus, a concatenation of time; this particular expression of territorial comprehension is not done within everyday time, but rather in mythical action or in ritual. To tell a myth thus maintains sharp the memory of a territory, and the topographic accidents, which constitute toponymy, represent knots of memories, which make it possible to couple an episode of a myth with another or a whole myth to another. These topographic accidents - that we commonly designate as "natural borders" - must thus also be seen as memory "couplings". As each one of these knots is a conceptual point of arrival and departure of a thought, it becomes, all at the same time, a limit and an interlocking unit.

In this sense, the toponyms of a territory are above all the elements of a narration, and the latter, consequently, a mental chart. One thus easily understands that the historical linearity introduced by the colonists' toponymy is, to be strictly accurate, disorienting for the Miraña. Since it does not couple with mythical imaginary of the territory, historical linearity disassociates the toponyms in order to singularize them in a linear time; each one becomes independent of the other. There is, for example, no semantic bond, in the toponymy of the colonists, between Araracuara and La Pedrera; each one returns, as a named element, at one singular moment in the historical linearity.

The time of myth, on the other hand, associates places with a narrative linearity (Pama, for example, Pá'à in Miraña, is the sound that the bark of the cosmic tree - the Cahuinari - produced while falling when the tree was being cut down). The territory in the myth is thus not opposed to the historical territory, but the linearity of the mythical narration is opposed to the linearity of historical time. The first bound together a territory in a pre-human temporality, which generally presided over its creation, whereas the second parcels out the territory in a juxtaposition of moments which, 
even if they are held on an identical place, must be separate to conform to their single place in historical temporality.

\section{Hunting territories, saltlicks and the National Natural Park of the Cahuinari}

In opposition to the preceding observations on territorial perception and separation, the Miraña recognise that a certain number of areas of their territories are reserved for, or "belong to" a specific maloca and to its dominant lineage. They are mainly hunting territories. These spaces are portions of streams of the main river or secondary affluent on which the maloca depends. Here, still, it is not a question of ground that is owned by a local group. It is much more a part of the game that lives there and that the local group estimates is its right to be the first to get, and even to use exclusively (the same applies for the fish that spawn in a maloca's waters). It should be stressed that game is divided into a certain number of categories including one, at the very least, which is the non-nauseating or not "stinking" game (mainly small game of the ground, which does not possess odoriferous glands: see below). This game is supposed to be partly nourished from the fruit of the old abandoned orchards, and partly from the still maintained gardens. It is opposed to the big and "stinking" game that is relegated to far distant places (i.e. in a non-anthropogenic forest). In fact, any portion of territory which is not under the responsibility of a maloca is regarded as accessible to whomever for hunting. Consequently, the responsibility that a particular maloca can claim over a given portion of territory is wider than the vicinity of its own maloca. It extends until it meets another maloca but stops when it reaches non-anthropogenic forest. It should be added that for game in general, it is thought as being under the responsibility of a Master of the Animals, and that it is not necessary to ask permission for hunting of anybody else but him.

A second portion of the territory grafts onto these hunting territories. This time, however, it is not reserved for a particular human maloca with its dominating lineage, but for the animals. Saltlicks, indeed, are known and named places in which the Miraña often abstain from hunting - more and more rarely today - even if they are assured of finding abundant game. Each one of these saltlicks is perceived as an animal maloca or, to be more precise, as a human maloca when it transforms into a feast place. The different animal species come there to enjoy the abundant salt it produces (it should be remembered that the indigenous groups of the area produce a vegetable salt mixed with tobacco that is of ritual use). The saltlicks are 
thus directly perceived as places toward which the animals converge in order to fill up with salt. There are thus, within the Miraña territory, some zones explicitly perceived as not being under human responsibility, and to whose inclinations the hunter exposes himself if he decides to hunt there. Non-anthropogenic forest is thus in the same kind of relation to these "animal malocas" as hunting territories are to humans: between them exists some kind of dependence. One cannot hunt without permission of the Master of the Animals.

At the very least, this partition of the territory takes into account nonhuman territories (territory of the primary forest, saltlicks and others) that form local topography in which a whole group of "people" is registered (i.e. human and non-human). It is in this particular context of environmental comprehension that the National Natural Park of Cahuinari came to be settled in 1987. It was superimposed on part of the territory which the current Miraña groups recognize as being under their responsibility (see also Echeverri and Botero 2002: 161-182 for a description of the various stages and results of this creation process). Without wanting to go into the details of the tumultuous relationship between the authorities of the Park and the ethnic group as a whole, it is symptomatic to focus on the juxtaposition of two types of space perceptions - that of the Miraña and finally that of a national state representative - which makes it possible to have a better understanding of the reasons for the repeated cohabitation failures.

The very idea of a natural reserve is, it seems to me, foreign to the groups of the area, not so much because such similar zones do not exist in the Miraña tradition - the case of the saltlicks we have just described attests to this - but because the hunter who engages in one of these reserved spaces takes a risk, even if it seems, for him, a calculated one. He knows that he goes into a space where taking game implies putting himself at the mercy of the Master of the Animals. This latter will not fail to send, in response to the killed game, diseases to destroy part of the hunter's family. The relationship that the Miraña, or the People of the Centre in general, maintain with diseases is not limited to a health problem of one individual; it also extends to the entire group under the responsibility of a local leader. To want thus to institute a space - the National Natural Park of the Cahuinari - in which the game stock is not under the responsibility of the Master of the Animals raises very serious interrogations, on the part of the Miraña, on the finality of such an initiative. 


\section{The "bench" or "seat" as concept of centre from which periphery is organised}

Such as I have described it, the Miraña model presents a double problem. First of all it is a comparative one, and secondly one of confrontation with the more general conception of the groups of the area. Indeed, if we define a territory as the portion of a continuous space delimited by borders, there is, after all, no problem in finding a centre inside it. Moreover, it does not matter, in a non-Amerindian - or occidental - model, where the centre is; the limits, in fact, take precedence over it. In this occidental model, it is the outside which models the contour of the territory, and the frictions - if frictions there must be - generally occur at its margins. The centre is of little importance; in fact it does not exist in the definition of the territory insofar as it does not modify anything in its contours. It is even necessary to radicalize this point of view by affirming that the occidental model is an expansionist one as long as it does not meet resistance that imposes a limit, which will be, moreover, quickly transformed into border.

In opposition, the establishment of a maloca by the Miraña - and more generally among People of the Centre - implies the creation, in its centre, of a "Place of ashes." It is a place where leaves are burned to produce ashes to be mixed with the coca powder and where a maloca chief receives the visitors and the male members of the house to distribute his coca and tobacco. Each one of these places receives a seat or bench that materializes the authority and extension of the aura of its owner. Only the creation of a centre permits the organization of the remaining territory related to this centre. But still here, the idea of the possession of the territory does not appear at all. It is much more an occupation of it that has to be marked, where occupation acts more as an establishment of sovereignty over a space than an appropriation of the ground.

By extension, each territory is ideally thought of as an earth in miniature, i.e. with an "entry" and an "exit," materialized on the river by rapids or falls which are as many crossing points in the underground world. The territory is also described as the "body" of humanity. The mouth of the river, which fits with rising, is opposed to setting, just as the "birthplace" is opposed to the mouth of the earth, the setting being a place of absorption and daily disappearance of the sun and the night stars: a passageway to the underground as territory of the dead. The underground paths that connect the saltlicks between them, for example, are seen similarly as the connections between organs within the human body. The limit between earth and sky does not have a border, since the sky is detached from it. 
The skin, in this way, is not really a boundary of the Self, but much more an identity marker. Applied to the society, or to the local group, the walls act as "bark" or a "rigid skin" of the maloca, and mark delimitation.

The effective centre to which the Miraña refer is included under a name that indicates the seats of the local leaders. These seats are emblematic of an authority perceived as anchored in a relationship to verticality between worlds (underground, terrestrial, and celestial) and with an upstream/ downstream axis (unceasingly renewed and moving human temporality). Linked to an anthropomorphized view of the territory, this "centre" is the point of intersection which makes it possible to perceive of the seat as a placenta, i.e. a primordial but definitive localization in an underwater space of the non-human or "savage" part of humans. It is also for this reason that clans look at their "birth places" as seats, places that remind them that they still possess something of the essence of the clan.

In fact, each one perceives himself/herself as a centre and one presents himself/herself as being from "downstream" or "upstream"; they are only relative positions. The Bora / Miraña opposition is equivalent to that existing between Murui / Muinane by the Uitoto. These are distinctions that partly cover those between "people of the 'stump', the downstream" (déhứkò muínáà) and "people of the 'top', the upstream" (núhkò muînáà) by the Miraña (as the same words are used for stump, river mouth and downstream and for top, river source and upstream). The social Self, thus, is the centre; the other human beings are upstream or downstream. Perceived on the whole of humanity, the "Real people" are in the centre of the world insofar as the upstream/downstream axis also covers an up/down opposition.

\section{Territory and odour}

When related to identity, the concept of territory is often expressed in terms of odours (páktrkit). In fact, it is more the identity, and therefore, to a certain extent, the odour, which marks the temporary territory of a unit. But this identity is also shared with other animal or vegetable species, a reason why it is not limited to a specific territory. Thus, and according to the Miraña, the territory of the peccaries is never fixed, but in constant displacement. In contrast, humans must regularly burn incense, kopal, to dissipatel the pathogenic odours from their collective habitat.

The social Self, here still, emanates from the establishment of a sphere where, paradoxically, the Other must be present in order to allow a certain fruitfulness. In this sense, the localities are never populated with 
representatives of only one filiation group. Women belong to other groups and "pollute" the patrilineage but, at the same time, allow for reproduction. There is thus, in a given place, the necessary presence of a combination of identities: the "territory" of a filiation group cannot be designated in an ideal adequacy in and of itself: it intrinsically needs the Other in its place. But this female presence is a pacified one, dominated, and brought back in order to allow for the perpetuation of a lineage. The situation is quite different with presences considered as intrusions and carrying their own odours (for a comparison between Andean and Amazonian categories of odours as perceptual schema, see Classen 1990).

In this, the skin is not a hermetic border: diseases are propagated and penetrate the person by means of the odour which an entity, an animal species, or a different human emits. In this still, the space of one's own odour - the territory - can be invaded by a nauseous odour, as it is explicitly described by the Miraña during the time of epidemics, or at the moment of certain temporalities (river risings and periods of fish migration that bring diseases from the lower Caquetá since they have been nourished with the wastes of the Whites). It is in this sense that the very idea of netting or palisades as border markers, which are supposed to exclude, is not primordial in the delimitation of relative identities. A person, a group, or a species can be absent, their "odour", on the contrary, very present: no materialization of delimitation can thus prevent the Other from taking possession of the Self (for a more general discussion of odour and Other see Classen 1993).

It is necessary to point out that the odours, of Oneself and/or the Other, always were for the Miraña and Bora a major concern. T. Whiffen, at the beginning of the last century, already pointed out that the apron of Bora men contained aromatic herbs in order to cover the body odour, but also, according to the comments of today's Miraña, to guard oneself against the aggressions caused by others (supposedly propagated by the odours).

We can analyse territories as something seen from the inside. The territory depends also on the kind of weapons used by enemies, or by Others seen as enemies, where frontiers - at least territorial frontiers- are of no use as a barrier in front of an aggression perpetrated by an enemy and that takes no material form. Diseases are the kind of lethal weapons that do not need territorialities to be used as weapons. For the Miraña, animals are the first to be blamed in the case of massive destruction. The material ways to transport diseases are smells: they can penetrate just about anything, save stronger or "fresher" ones, that stop the intrusion. "Others" -meaning by that, other people or entities- are seen as pathogenic in as much as they 
have stronger smell, or if it is brought into contact with a weaker one (as with children).

This way of thinking strangely relates most recently to Weapons of Mass Destruction (WMD). Here territories are of no importance and the overall presence of a super-potent enemy fed up with WMD is, as in the Amerindian case, a political construction permitting the development of the image of an enemy, thus justifying a hard-line leadership and creating a common and shared smell of fearfulness. In the Amerindian case, this notion of "smell" can be linked to a sphere that a shaman can depict as his "domain", and where he claims that nobody enters physically or spiritually without being aware of it. In this sense, the identities are not defined according to external frontiers but according to "centres" - malocas, saltlicks, trunks, etc. Moving away in distance from these finally dissipates odours to the point of not being perceptible.

Thus, there are no true frontiers; the odours intermingle, and one vanishes in front of another. Sometimes, one can still distinguish the first, sometimes the other, but often they mix and any boundary - properly a categorical creation in the continuum- becomes unperceivable. It is at this moment that the Miraña fantasise. They bring out the flags and the placards, and post up identities inherited from colonists' denominations (i.e. imposed by others). It is when they institute the time of folklore..., beautiful but without odours, sanitized, a watered down reflection of themselves. In these terms it could be thought of as an aura, i.e. of something perceptible by someone, but which is in constant evolution, passing from virulence to absence without being modified by frontiers.

\section{Conclusion}

Looking at the conceptions of an Amazonian Indian group on territories and boundaries, it appears that they are undeniably associated with that of identity. But the ways that they are linked seem to be opposite to the ways that we are commonly used to; territory is a-historical and is understood as a world before being a territory. Space, in this sense, is cognitively adjusted in such a manner that it reflects more a mythological than an historical time. Miraña landscape is telling a story which is not issued from historical happenings but from mythical narrations.

The intrusion of colonists for more than three centuries in the area has led to profound changes. The first of these was a demographic breakdown that resulted in sociological, as well as ethnic reconstruction. Although one 
would be expected to find an intrusion of the historical way of thinking which does exist but has no expression in Miraña tradition - the manner of conceptualising territory did not integrate this. To the Miraña people, the perception of their landscape generates a remembrance that goes back to mythical times; and the way of expressing this is a narration that links places together with events, temporality, space and toponymy. For the Miraña, the landscape needs something else to become territory: smells. Occupying the land means having an existence that expresses itself through odours. And it also needs a centre from which the group radiates. Boundaries are thus constantly reshaped according to the social Self of a group, its political needs, and the "pestilential" vitality of neighbours.

\section{References}

Classen, Constance. 1990. Sweet colors, fragrant songs: sensory models of the Andes and the Amazon. American Ethnologist 17(4): 722-735.

Classen, Constance. 1992. The odor of the other: olfactory symbolism and cultural categories. Journal of the Society for Psychological Anthropology ETHOS 20(2):133-166.

Domínguez, Camilo and Augusto Gómez. 1994. Nación y Etnias: Los conflictos territoriales en la Amazonia 1750:1933, COAMA, Bogotá.

Echeverri, Juan Alvaro and Rodrigo Botero. 2002. Dos 'centros de pensamientos' para el manejo y conservacion del Cahuinari. In Ministerio del Medio Ambiente, ed. Parques con la gente II: 161-182. Bogotá: Parques Nacionales de Colombia.

Ingold, Tim. 2000. The perception of the environment. Essays in livelihood, dwelling and skill. London and New York: Routledge.

Karadimas, Dimitri. 1997. Le corps sauvage. Idéologie du corps et représentations de l'environnement chez les Miraña d'Amazonie colombienne. Doctoral Thesis. Université de Paris X (Nanterre).

Karadimas, Dimitri. 1999. L'impossible quête d'un Kalos Thanatos chez les Miranha d'Amazonie colombienne. Journal de la Société des Américanistes 85: 387-398.

Karadimas, Dimitri. 2000. Parenté en esclavage. Pratiques matrimoniales et alliances politiques chez les Miraña d'Amazonie colombienne. Droit et cultures 39: 81-100.

Spix, Joh. Bapt. von and Carl Friedr. Phil. von Martius. 1980 (1831). Reise in Brasilien, in den Jahren 1817-1820. Stuttgart: Brochaus Komm.Gesch. GmbH., Abt. Antiquarium, III Bände.

Stanfield, Micheal Edward. 1998. Red Rubber, Bleeding Trees: Violence, Slavery, and Empire in Northwest Amazonia, 1850-1933. Albuquerque: 
University of New Mexico Press.

Taylor, Anne-Christine. 1993. Remembering to forget: identity, mourning and memory among the Jívaro. Man 28(4): 653-678.

Whiffen, Thomas. 1915. The North-West Amazons. Notes of some months spent among cannibal tribes. London: Constable \& Company Ltd. 